\title{
Neurology
}

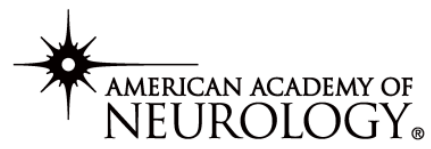

The most widely read and highly cited peer-reviewed neurology journal The Official Journal of the American Academy of Neurology

Neurology Publish Ahead of Print DOI: 10.1212/WNL.0000000000012301

\section{Teaching NeuroImages: Central Pontine Myelinolysis in Diabetic}

\section{Ketoacidosis}

Natalia Gonzalez Caldito ${ }^{1}$, Nurose Karim¹, Mehari Gebreyohanns ${ }^{1}$

${ }^{1}$ Department of Neurology \& Neurotherapeutics, University of Texas Southwestern Medical Center, Dallas, TX, USA

Neurology® Published Ahead of Print articles have been peer reviewed and accepted for publication. This manuscript will be published in its final form after copyediting, page composition, and review of proofs. Errors that could affect the content may be corrected during these processes. 
Search terms: Central pontine myelinolysis, osmotic demyelination syndrome, pons, brainstem, metabolic diseases.

Submission type: Teaching NeuroImage (resident \& fellow section)

Title character count (with spaces): 54

Number of tables: N/A

Number of figures: 1

Word count abstract: N/A

Word count of manuscript: 150

Corresponding author: Mehari Gebreyohanns, MD, FAHA, FAAN, mehari.gebreyohanns@utsouthwestern.edu

\section{Disclosure}

Natalia Gonzalez Caldito, Nurose Karim, and Mehari Gebreyohanns report no disclosures relevant to the manuscript.

Written consent was not obtained. 


\section{DESCRIPTION}

Central Pontine Myelinolysis (CPM) is a clinically heterogeneous neurological disorder of demyelination in the pons, usually from rapid correction of hyponatremia. ${ }^{1,2}$

A 38-year-old woman with uncontrolled type $1 \mathrm{DM}$ (hbA1c 12.8\%) was admitted for diabetic ketoacidosis $(731 \mathrm{mg} / \mathrm{dl}$ blood glucose). Hyperglycemia was corrected within 24 hours to $129 \mathrm{mg} / \mathrm{dl}$. Upon presentation, the sodium and potassium levels were 139 and $3.9 \mathrm{mmol} / \mathrm{L}$ respectively, remaining stable until discharge. There was no history of malnutrition nor alcohol abuse.

Four days later, she developed acute diffuse pyramidal weakness. Brain MRI revealed symmetric restricted diffusion in the pons with a normal MR angiography (Figure 1). She remained stable and was discharged to a rehabilitation facility.

Diabetic ketoacidosis is an uncommon cause of CPM with uncertain physiopathology. ${ }^{3}$ Here, it is plausible that a rapid drop in osmolality in a chronic state of high osmolality (uncontrolled DM) lead to CPM. A slower correction of hyperglycemia could have possibly prevented it. 


\section{Appendix 1. Authors}

\begin{tabular}{|l|l|l|}
\hline Name & Location & Contribution \\
\hline Natalia Gonzalez & University of Texas & Patient management, literature review, \\
& Southwestern Medical Center & gathered data and drafted the manuscript \\
Nurose Karim, MD & University of Texas & Patient management and revised the \\
& Southwestern Medical Center & manuscript for intellectual content \\
\hline Mebreyohanns, MD & Southwestern Medical Center & manuscript for intellectual content \\
\hline
\end{tabular}

Acknowledgements: N/A 
Teaching Slides --- http://links.lww.com/WNL/B447

\section{BIBLIOGRAPHY}

1. Fitts W, Vogel AC, Mateen FJ. The changing face of osmotic demyelination syndrome: A retrospective, observational cohort study. Neurology: Clinical Practice. Epub ahead of print 26 August 2020. DOI: 10.1212/CPJ.0000000000000932.

2. Rodríguez-Velver KV, Soto-Garcia AJ, Zapata-Rivera MA, et al. Osmotic Demyelination Syndrome as the Initial Manifestation of a Hyperosmolar Hyperglycemic State. Case Reports in Neurological Medicine 2014; 2014: e652523.

3. Matías-Guiu JA, Molino ÁM, Jorquera M, et al. Pontine and extrapontine myelinolysis secondary to glycemic fluctuation. Neurologia 2016; 31: 345-347. 
Figure 1: Central pontine myelinolysis in diabetic ketoacidosis

T2-FLAIR revealing symmetric hyperintensities centered in the pons (A) with restricted diffusion (B). T1 post contrast with gadolinium demonstrated no enhancement(C).

FLAIR: fluid-attenuated inversion recovery; DWI: diffusion-weighted magnetic resonance imaging; Post GAD: post gadolinium. MRI: Magnetic Resonance Imaging

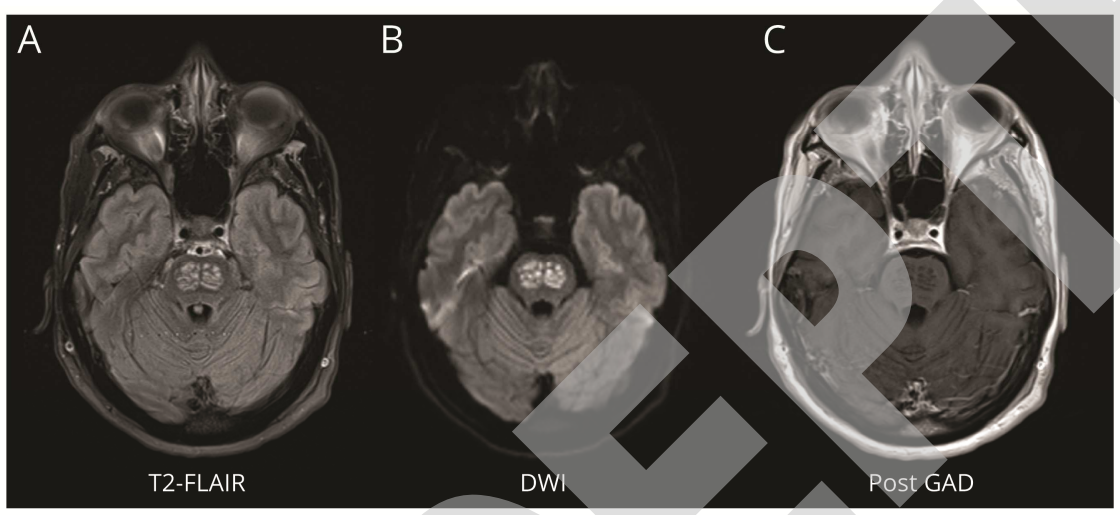




\title{
Neurology
}

\author{
Teaching NeuroImages: Central Pontine Myelinolysis in Diabetic Ketoacidosis \\ Natalia Gonzalez Caldito, Nurose Karim and Mehari Gebreyohanns \\ Neurology published online June 2, 2021 \\ DOI 10.1212/WNL.0000000000012301
}

This information is current as of June 2, 2021

Updated Information \& Services

Subspecialty Collections

Permissions \& Licensing

Reprints including high resolution figures, can be found at:

http://n.neurology.org/content/early/2021/06/02/WNL.0000000000012301. citation.full

This article, along with others on similar topics, appears in the following collection(s):

All Clinical Neurology

http://n.neurology.org/cgi/collection/all_clinical_neurology

All Demyelinating disease (CNS)

http://n.neurology.org/cgi/collection/all_demyelinating_disease_cns

All Medical/Systemic disease

http://n.neurology.org/cgi/collection/all_medical_systemic_disease

Endocrine

http://n.neurology.org/cgi/collection/endocrine

MRI

http://n.neurology.org/cgi/collection/mri

Information about reproducing this article in parts (figures,tables) or in its entirety can be found online at:

http://www.neurology.org/about/about_the_journal\#permissions

Information about ordering reprints can be found online:

http://n.neurology.org/subscribers/advertise

Neurology ${ }^{\circledR}$ is the official journal of the American Academy of Neurology. Published continuously since 1951, it is now a weekly with 48 issues per year. Copyright (C) 2021 American Academy of Neurology. All rights reserved. Print ISSN: 0028-3878. Online ISSN: 1526-632X.

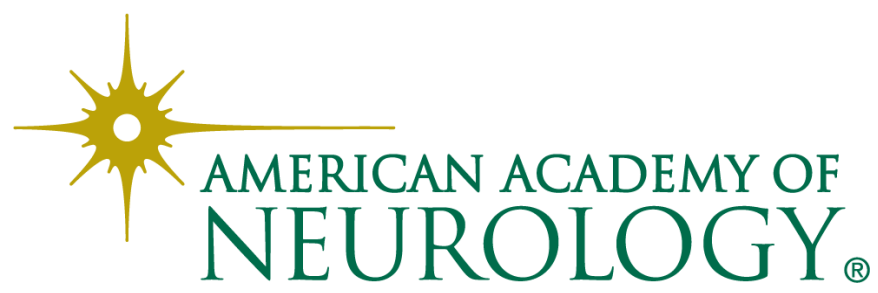

